\title{
Economic Growth and Health Expenditure Analysis for Turkey: Evidence from Time Series
}

\author{
Ethem Esen ${ }^{1} \cdot$ Merve Çelik Keçili ${ }^{2}$
}

Received: 30 June 2020 / Accepted: 2 April 2021 / Published online: 15 April 2021

(C) The Author(s), under exclusive licence to Springer Science+Business Media, LLC, part of Springer Nature 2021

\begin{abstract}
This study aims to investigate the effects of health expenditure on economic growth in Turkey. For this purpose, time series data of Turkey over the period 1975-2018 were evaluated. Moreover, household consumption, life expectancy at birth, trade, and foreign direct investments were added as control variables. Cointegration analysis was performed to test whether all variables are cointegrated in the long term. Causality test was successfully employed to investigate the relationship between health expenditure and economic growth in the short term. The achieved results exhibited that Johansen Cointegration test results suggest the existence of cointegration among all variables in the long term. In addition, the Granger causality test results indicate unidirectional causality from health expenditure to economic growth in the short term. Existence of a long-term relationship among related variables and a short-term relationship between health expenditure and economic growth displays the importance of investments on health care services in Turkey. Therefore, investments in the health sector should be encouraged and the share allocated by the government for health expenditures from the budget should be increased in Turkey.
\end{abstract}

Keywords Human capital · Health - GDP per capita · Health expenditure per capita · Vector error correction model

JEL Classification $\mathrm{I} 15 \cdot \mathrm{O} 10 \cdot \mathrm{C} 01$

Merve Çelik Keçili

mervecelik722@anadolu.edu.tr

1 Economic and Administrative Faculty, Department of Economics, Anadolu University, 26470 Eskişehir, Turkey

2 Open Education Faculty, Department of Economics and Administrative Programs, Anadolu University, 26470 Eskişehir, Turkey 


\section{Introduction}

Human capital accumulation fosters economic growth (Romer, 1990). The human capital theory indicates that people's human capital savings lead to an increase in their fruitfulness in the market area and non-market sector (Grossman, 1999). Health is one of these determinants of the human capital theory (i.e., Becker, 1964; Mincer, 1974). It is also an important determinant of economic development and well-being of the population. The health-led growth hypothesis considers health as a capital. The health-led growth hypothesis emphasized that health investment causes an increase in productivity, and thus in income per capita and economic growth (Piabuo \& Tieguhong, 2017). In the 1980s, a new approach named as "endogenous growth model" was developed by Romer (1986). This approach describes that the educated, healthy, and skilled labor are more efficient and able to use technology more productively. At the same time, health investments ensure labor productivity to be increased; in this way, income and wellbeing levels of population significantly increase (Mushkin, 1962). Human capital is accepted as a significant determinant of health and gross domestic product (GDP) per capita. Healthier people who expect to live longer have more abilities to get human capital skills (Hansen, 2013).

Various studies have investigated health expenditure and economic growth as human capital factors by using various perspectives all over the world. Health levels of the population affect not only domestic product but also welfare. Thus, it is very crucial for academicians to investigate the relationship between health expenditure and other macroeconomic indicators. Empirical studies suggest that some indicators such as life expectancy are affected by healthcare spending which vary in different countries. This influence of health expenditure may also be heterogeneous across the world's life expectancy distribution (Obrizan \& Wehby, 2018). Moreover, the health-led growth hypothesis asserts the contribution of the healthcare spending on economic growth; health investments increase physical and human capital accumulation. This leads to economic growth (Bloom \& Canning, 2000). The relationship between income and healthcare spending is one of the main subjects in health economics literature such as this hypothesis.

The relationship between economic growth and health expenditure has been investigated using various methods. The achieved results from these studies demonstrate that this relationship varies based on the conditions and characteristics of the related country. There is no common conclusion especially by investigating short-run and long-run causality to analyze the relationship between health expenditure and economic growth.

In this study, the effects of health expenditure influence on economic growth in Turkey were investigated by applying time series methods. Household consumption per capita, trade, life expectancy at birth, and foreign direct investment (FDI) were also added in order to investigate the impact of health expenditure on economic growth in Turkey. For this purpose, the impact of these variables on economic growth has been investigated. The rest of the paper is structured as follows: 
"Health Expenditure in Turkey" involves the summary of health expenditure in Turkey, "Empirical Literature" presents empirical literature, "Data and Methodology" comprises data and methodology, and "Empirical Results and Analysis" presents empirical results and analysis. Finally, conclusion and policy implication are discussed.

\section{Health Expenditure in Turkey}

Health is one of the most crucial factors for the economic growth and development of households, nations, and even all over the world which was emphasized in the report of Sustainable Development Goals published by the United Nations. These goals are key factors for a sustainable and better future. One of these goals is good health and well-being. The health system succeeded with a noticeable improvement with the Health Transformation Program (HTP) in Turkey. The most comprehensive reforms were carried out after implementing this program in 2003. Before 2003, health insurance system funds were organized by various regulations. In 1965, The Active Civil Servant Scheme was created and funded by government budget and allocated to civil servants who work actively. In 1992, The Green Card Scheme financed by the Ministry of Health was established to support people who earn lower than one-third of the minimum wage level. The Government Employees Retirement Fund was founded in 1949, and civil servants who are retired financed this system. The Social Insurance Agency of Merchants, Artisans, and Self Employed (BAĞKUR) provided health services to self-employed workers and are financed by earnings gained by these people since 1987. In 1964, the Social Insurance Organization established and covered the biggest part of the population such as white-blue collar workers in private and public sectors and these workers were financed by payroll wages (Yıldırım \& Yıldırım, 2011).

Radical differences also have taken place in healthcare finance since 2003. Health services which serve the population such as the private and public sectors are financed by the social security scheme. The Ministry of Health in Turkey is responsible for providing care systems through facilities. The total current healthcare expenditure of GDP rises from $8.6 \%$ in 2000 to $10 \%$ in 2016 . The share of the government in health expenditure is $74 \%$ (World Bank, 2020). The HTP provided a decrease in restrictions, reaching health facilities. These improvements have a big role in this rise. The health insurance system, financial easiness during illness, and access to healthcare facilities provided the impact of the HTP to be improved especially for poorer citizens.

Figure 1 shows the proportion of health expenditure on GDP in 1999 and 2018 in Turkey. The rate of health expenditure extends around 5\%. The peak occurs especially in the year of 2009 and closes to $6 \%$. A decrease extends following that year, and the proportion of the health expenditure is particularly below the rate of $5 \%$ after 2010 .

Table 1 displays the allocation of total health expenditure of the general government and private sector for the period of 2001-2018 for Turkey. According to the table, the share of government expenditure is higher compared to that of the private sector for all the years and the rate of this sharing is changeable considering 


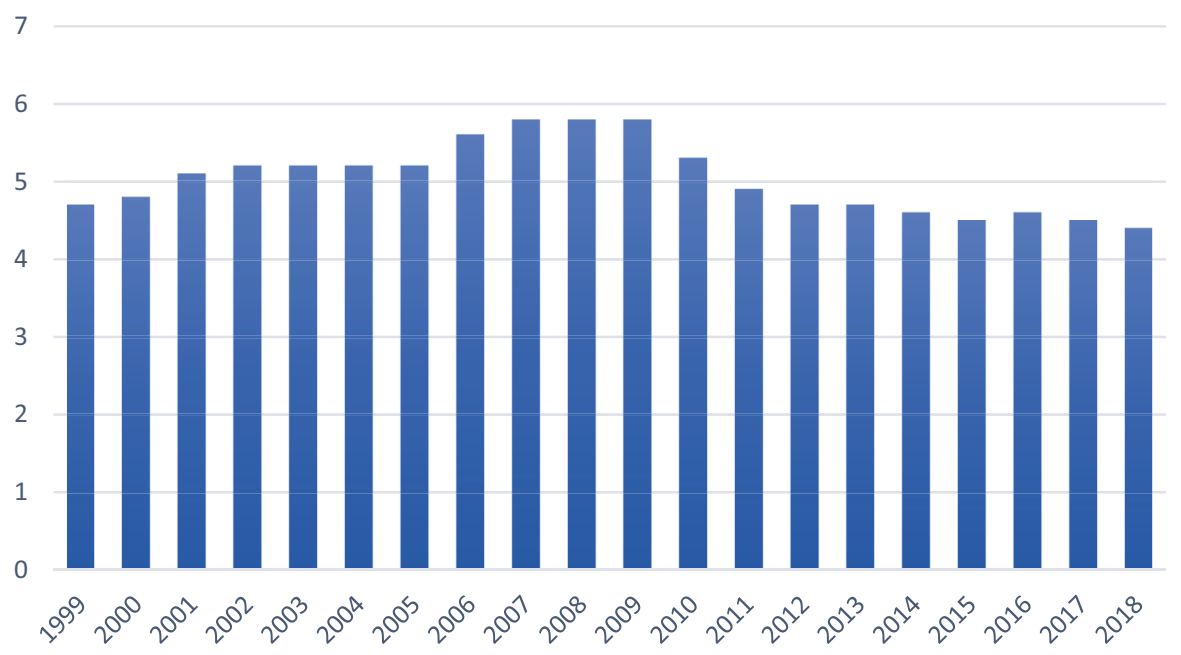

Fig. 1 Health expenditure (\% of GDP) All data are from Turkstat (2020)

the selected years. The rate of increase in the government expenditure especially tends to rise in 2003 and progressing years until 2014. The number of general total government expenditure is 44289 million dollars in 2013. HTP became prevalent in 2003; thus, continuous improvements related to this program can be accepted as the reason for this high rise. Social security constitutes the largest part of general government expenditure. The peak of health expenditure in social security takes place as 24.6 billion dollars in 2013. The number of private sector expenditures tends to reach higher after HTP improvement. The highest ratio of private sector expenditure in selected years can be seen as 12.5 billion dollar in 2007 .

\section{Empirical Literature}

The reported studies on investigation of the relationship between health expenditure and economic growth were carried out for many developing and developed countries. Particularly in developing countries, for example, Elmi and Sadeghi (2012) examined the cointegration and causality of health expenditure and economic growth for developing countries in the years from 1990 to 2009. In their study, the achieved results showed that there is short-run causality from economic growth to health expenditure. In addition, economic growth exhibits a long-run relationship with health expenditure. Piabuo and Tieguhong (2017) studied the influence of healthcare spending on the economic growth in selected African countries and central African states. The obtained results showed that the economic growth displays a long-run relationship of healthcare spending. In addition, healthcare expenditure also displays positive influences on economic growth. Sethi et al. (2020) investigated the short-run and long-run impacts of health expenditure, domestic and foreign investments, and institutional quality on economic growth for South Asian countries. The results indicate 


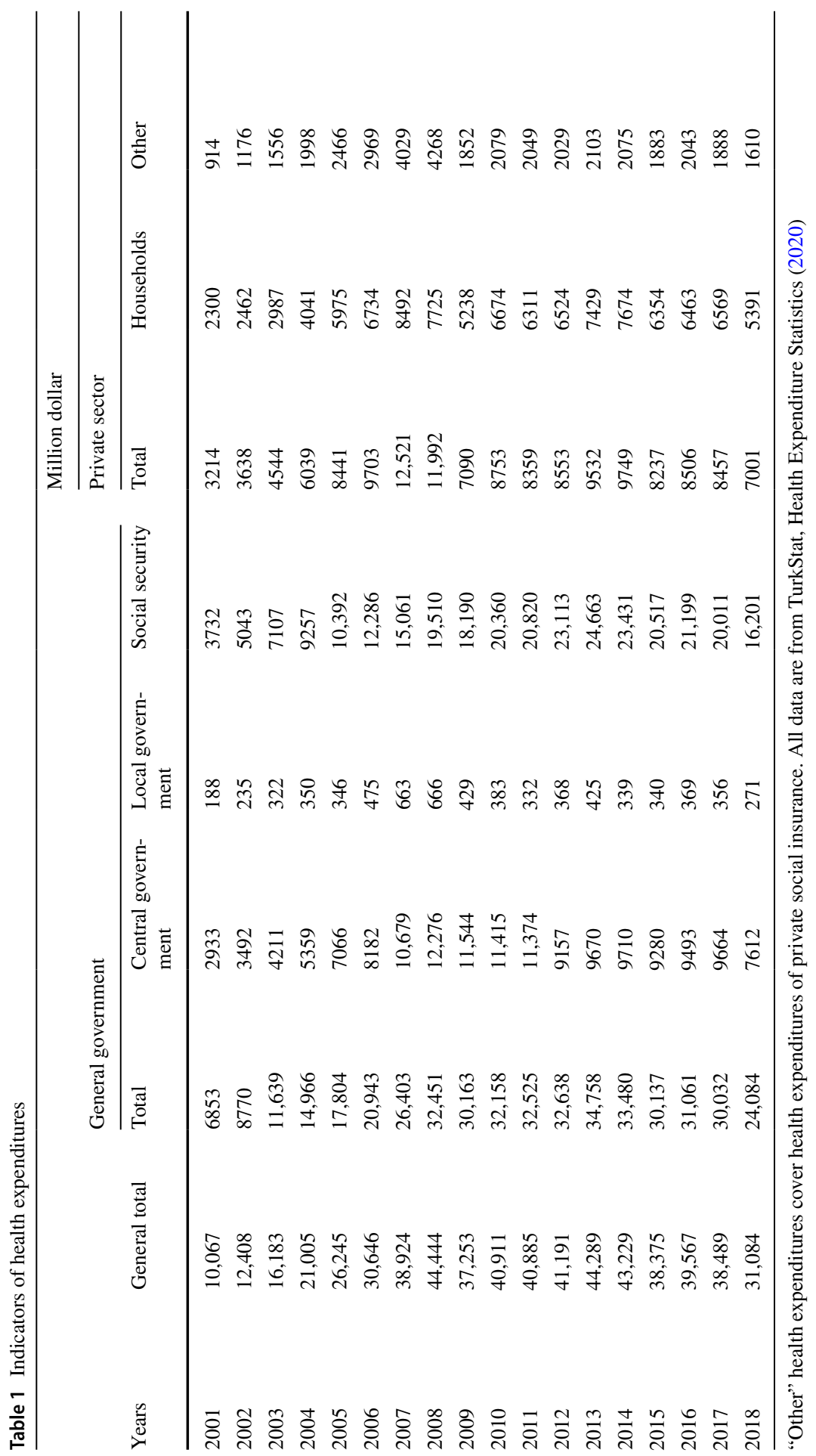


that there is bidirectional causality between health expenditure and economic growth in the short term. Eggoh et al. (2015) reported a negative relationship between public health expenditure and economic growth for 49 African countries over the period 1996-2010. In another interesting report, Yang (2020) also revealed that health expenditure negatively affects the economic growth when human capital level is low in 21 developing countries for the period of 2000 to 2016.

On the other hand, various studies have been reported by using the data set of developed countries. For example, Moscone and Tosetti (2010) investigated the long-term relationship between health expenditure and economic growth over the period 1980-2004 in 49 US states. The obtained results confirmed that there is a long-term relationship between health expenditure and economic growth. According to a crucial study reported by Halıc1-Tülüce et al. (2016), the causality test of economic growth and health expenditure in high- and low-income countries for the period of 1995-2012 and 1997-2009 was examined. It was found that there is a bidirectional relationship between the related variables in the short run. There is also one-way causality from economic growth to health expenditure in the long run. Dreiger and Reimers (2005) studied the relationship between health expenditure and economic growth in 21 OECD countries for the period 1975-2001, and the results indicate that there is a long-run relationship between GDP per capita, health expenditure, and proxies for medical progress. Çetin and Ecevit (2011) tested the impact of health expenditure on economic growth of 15 OECD countries for the period 1990 to 2006. The results indicate that there is no significant relationship between health expenditure and economic growth. Khan and Bashar (2015) reported the results of the relationship between economic growth and social expenditure including public health expenditure in Australia and New Zealand from 1980 to 2012. According to the results, health expenditure is one of the main determinants of growth. Moreover there is one-way causality from health expenditure to economic growth in Australia in the short term. Therefore, the direction of relationship is from economic growth to health expenditure in New Zealand in the short term.

There are also different variations in empirical studies that investigate the impact of healthcare spending on economic growth in Turkey. It can be noticed that the results of the studies show divergence of cointegration and causality direction of health expenditure and economic growth in the long run and short run. In an important work conducted by Atilgan et al. (2017), the evaluation of the relationship between health expenditure and economic growth in the years from 1975 to 2013 was tested. The results of these models show a long-run relationship and short-run relationship between the selected variables. In another interesting work reported by Erçelik (2018), the long-run cointegration in 1980-2015 in Turkey was also investigated. The obtained result suggests that variables are cointegrated and the longrun relationship is significant. Kiymaz et al. (2006) tested the long-run relationship between health expenditure and economic growth and causality in Turkey. They confirmed a long-run relationship and one-way causality from income to health expenditure. Aydemir and Baylan (2015) examined the causality for the period of 1998-2012 for Turkey. They noticed that health expenditure does Granger cause economic growth. In a crucial paper carried out by Akıncı and Tuncer (2016), the causality and long-run cointegration for the period of 2006:Q1 and 2016:Q2 in 
Turkey were investigated. The achieved outputs from this study indicate that the relationship between economic growth and health expenditure exists in the long run. In addition, there is bidirectional causality of these two variables.

The literature shows that there are a number of reported studies about the relationship between economic growth and health expenditure. By evaluating the longrun and short-run causality for the confirmation of the relationship between healthcare spending and economic growth, there is no common result in the existence and direction of the causality in studies. The differences of results may stem from variables, specific reasons of countries, or methods. Thus, it is important to use the proper variables and methods for the related countries to get reliable results. This paper examined whether there is a long-run association of economic growth and health expenditure or not. Their existence and direction of causality were also investigated in this study. In addition, the impact of a health expenditure shock on GDP per capita is studied using impulse-response function. For this purpose, firstly, unit root tests including augmented Dickey-Fuller (ADF) was employed. Secondly, existence of the cointegration was analyzed and in the third stage existence and direction of causality were investigated using the vector error correction model (VECM). Cointegration among the variables was employed using the Johansen and Juselius technique. The Granger causality test, which determines the existence and direction of causality of variables including healthcare expenditure and economic growth, was performed in the short term. Finally, impulse-response function was employed for the investigation of the impact of health expenditure on GDP per capita.

\section{Data and Methodology}

Endogenous growth models involve the influences of healthcare spendings on economic growth and development. These models concentrate on the influence of human capital theory on economic growth. In literature, various models were reported on positive influences of human capital on economic growth. Lucas (1988) contributes to the field of economic growth: growth and human capital. Barro (1991) highlights that human capital is a crucial parameter for income per capita. This crucial influence of human capital on economic growth by applying the augmented Solow growth model was also confirmed by Mankiw and colleagues in 1992 (Mankiw et al. 1992).

In this study, the variables in the identified model are inspired by the work which was carried out by Piabuo and Tieguhong. Equation (1) highlights the importance of human capital accumulation. The original model was updated considering the human capital theory. Economic growth and health expenditure are used as proxy variables of human capital.

In this way, the functional form of econometric model can be indicated as follows:

$$
\begin{aligned}
\text { GDP per capita }=\alpha & + \text { Bhealth expenditure per capita } \text { c }_{t}+\text { Nlife expectancy }_{t} \\
& +{\text { Shousehold consumption per } \text { capita }_{t}} \\
& + \text { strade }_{t}+\lambda f d i+\varepsilon_{t}
\end{aligned}
$$

$\alpha, \beta, \wedge, \delta, \xi$, and $\lambda$ are coefficients related to the model. 
Table 2 Variable descriptions

\begin{tabular}{lll}
\hline Symbol & Indicator & Source \\
\hline GDP & Gross domestic product per capita (logged) & WDI \\
Health & Health expenditure per capita (logged) & OECD \\
Life & Life expectancy at birth & WDI \\
Cons & Household consumption per capita (logged) & OECD and WDI \\
Trade & Trade & WDI \\
Fdi & Foreign direct investment (logged) & WDI \\
\hline
\end{tabular}

$t=$ time from 1975 to 2018 .

This paper employs annual data for the period from 1975 to 2018 in Turkey. A number of different variables including life expectancy, health expenditure per capita (logged), GDP per capita, trade, household consumption per capita (logged), and FDI (logged) were carefully investigated. The annual data of the variables were provided by the OECD and World Bank Indicator (WDI).

Health is used as a component in this study as one of the most essential indicators of human capital. Also, life expectancy at birth of individuals is accepted as a proxy of health in the studies which contain kinds of human capital. Health expenditure and life expectancy at birth are used as an essential parameter for health in the study. Many studies also suggest that the relationship between human capital and trade displays an influence as one of the main determinants of economic growth. In this work, the impact of the trade on the economy is also emphasized. Household final consumption represents the largest share of final uses in GDP. Moreover, it is crucial as a variable for demand analysis of economics. FDI is also considered an important control variable to capture the effect of health expenditure on growth. Variable descriptions, indicators of variables, and sources are displayed in Table 2.

Table 3 Augmented DickeyFuller test

\begin{tabular}{|c|c|c|c|c|}
\hline \multirow[t]{2}{*}{ Variables } & \multicolumn{2}{|l|}{ Level } & \multicolumn{2}{|c|}{ 1st difference } \\
\hline & $\begin{array}{l}\text { Trend and } \\
\text { intercept }\end{array}$ & Probability & $\begin{array}{l}\text { Trend and } \\
\text { intercept }\end{array}$ & Probability \\
\hline GDP & -2.91 & $(0.21)$ & -4.65 & $(0.0001)$ \\
\hline Health & -2.48 & $(0.38)$ & -4.70 & $(0.0001)$ \\
\hline Life & 2.15 & (0.99) & -6.98 & $(0.0001)$ \\
\hline Cons & -2.15 & $(0.51)$ & -4.62 & $(0.0001)$ \\
\hline Trade & -3.03 & $(0.17)$ & -5.42 & $(0.0001)$ \\
\hline Fdi & -1.84 & $(0.64)$ & -5.77 & $(0.0001)$ \\
\hline
\end{tabular}


Table 4 Optimal lag length selection

\begin{tabular}{lllll}
\hline Lag & AIC & HQ & SC & FPE \\
\hline 1 & -28.433 & -27.790 & -26.641 & $4.593 \mathrm{e}-13$ \\
2 & -31.671 & -30.477 & -28.344 & $2.063 \mathrm{e}-14$ \\
3 & -32.762 & -31.017 & -27.899 & $1.016 \mathrm{e}-14$ \\
4 & -36.015 & -33.720 & -29.617 & $9.514 \mathrm{e}-16$ \\
5 & -39.332 & -36.486 & -31.398 & $2.677 \mathrm{e}-16$ \\
\hline
\end{tabular}

\section{Empirical Results and Analysis}

In this study, time series analysis is used to investigate the relationship between health expenditure and economic growth in Turkey. For this purpose, firstly, the unit root test was used to control the stationarity of the series. If a probability distribution of series is constant over time, the series is accepted as stationary. Dickey and Fuller $(1979,1981)$ developed the augmented Dickey-Fuller (ADF) test which is mostly used as a unit root test. This test has a parametric approach and developed the Dickey-Fuller (DF) approach. The ADF test determines the presence of unit root in series by performing the ordinary least squares (OLS) estimator.

There are stationarity test results of variables shown in Table 3. The test results indicate the level and trend with intercept types of variables. The results of the stationarity test for all variables at level show that the variables which are used in the econometric model are non-stationary. The null hypotheses of unit root cannot be rejected at level for all variables. In the second stage, the null hypothesis of unit root is rejected; in other words, the first difference results of all variables are stationary and the series are integrated of order 1 .

It is concluded that all variables are $I(1)$ by using the ADF unit root test. The following stage is to investigate if there is a long-run relationship among variables including GDP per capita, health expenditure per capita, life expectancy at birth, trade, consumption per capita, and FDI. The cointegration test reveals the presence of a long-run relationship among these variables. The null hypothesis indicates a lack of cointegration, and an alternative hypothesis remarks the existence of cointegration. The results of the two Johansen cointegration test procedure statistics, including trace statistics and eigenvalue statistics, are evaluated for the cointegration test (Johansen \& Juselius, 1990).

Table 5 Cointegration test result

\begin{tabular}{|c|c|c|c|c|c|c|c|c|}
\hline \multicolumn{5}{|c|}{ Eigenvalue } & \multicolumn{4}{|l|}{ Trace } \\
\hline $\mathrm{H}_{0}$ : rank & Statistic & 0.10 & 0.05 & 0.01 & Statistic & 0.10 & 0.05 & 0.01 \\
\hline 0 & 116.78 & 36.25 & 39.43 & 44.59 & 295.67 & 85.18 & 90.39 & 104.20 \\
\hline 1 & 64.97 & 30.84 & 33.32 & 38.78 & 178.89 & 66.49 & 70.60 & 78.87 \\
\hline 2 & 61.82 & 24.78 & 27.14 & 32.14 & 113.93 & 45.23 & 48.28 & 55.43 \\
\hline 3 & 29.22 & 18.90 & 21.07 & 25.75 & 52.11 & 28.71 & 31.52 & 37.22 \\
\hline 4 & 19.27 & 12.91 & 14.90 & 19.19 & 22.90 & 15.66 & 17.95 & 23.52 \\
\hline 5 & 3.63 & 6.50 & 8.18 & 11.65 & 3.63 & 6.50 & 8.18 & 11.65 \\
\hline
\end{tabular}


Before the cointegration test procedure, selection of the optimal lag number is necessary to analyze the determination of the existence of cointegration. The ongoing issue is to determine optimal lag length criteria for a VAR. The optimal lag length result is shown in Table 4. There are more than one selection criteria on the table. Akaike information criteria (AIC) are applied for the selection of optimal lag length. According to AIC, the optimal lag length is 5.

The Johansen test procedure results in Table 5 report the eigenvalue and trace statistics to determine the cointegration relationship in the long run using the lag length of 5 . The results reveal that the null hypothesis can be rejected at $1 \%, 5 \%$, and $10 \%$ significance levels of the eigenvalue test and trace test. Variables exhibit a longrun relationship between five cointegration vectors. It means that there are long-run

Table 6 Granger causality test result

\begin{tabular}{lrl}
\hline Null hypothesis & Chi-sq & Probability \\
\hline Health does not Granger cause GDP & 11.469 & 0.022 \\
Life does not Granger cause GDP & 8.899 & 0.064 \\
Cons does not Granger GDP & 2.394 & 0.664 \\
Trade does not Granger cause GDP & 7.661 & 0.105 \\
Fdi does not Granger cause GDP & 5.570 & 0.234 \\
GDP does not Granger cause health & 4.818 & 0.307 \\
Life does not Granger cause health & 9.589 & 0.049 \\
Cons does not Granger cause health & 4.006 & 0.405 \\
Trade does not Granger cause health & 6.600 & 0.159 \\
Fdi does not Granger cause health & 6.986 & 0.137 \\
GDP does not Granger cause life & 6.309 & 0.177 \\
Health does not Granger cause life & 1.914 & 0.752 \\
Cons does not Granger cause life & 7.452 & 0.114 \\
Trade does not Granger cause life & 3.932 & 0.415 \\
Fdi does not Granger cause life & 0.988 & 0.912 \\
GDP does not Granger cause Cons & 2.243 & 0.691 \\
Health does not Granger cause Cons & 6.690 & 0.153 \\
Life does not Granger cause Cons & 7.617 & 0.107 \\
Trade does not Granger cause Cons & 3.662 & 0.454 \\
Fdi does not Granger cause Cons & 2.518 & 0.641 \\
GDP does not Granger cause trade & 6.035 & 0.197 \\
Health does not Granger cause trade & 9.335 & 0.053 \\
Life does not Granger cause trade & 7.131 & 0.130 \\
Cons does not Granger cause trade & 7.957 & 0.093 \\
Fdi does not Granger cause trade & 12.382 & 0.015 \\
GDP does not Granger cause Fdi & 9.335 & 0.053 \\
Health does not Granger cause Fdi & 0.679 & 0.954 \\
Life does not Granger cause Fdi & 10.205 & 0.037 \\
Trade does not Granger cause Fdi & 11.262 & 0.024 \\
\hline
\end{tabular}


and stable equilibrium relations among variables. These results affirmed with that of Ak (2012), Akar (2014), and Aydemir and Baylan (2015) who tested the economic growth function using health expenditure as a proxy variable in Turkey and determined the order-1 integration and cointegration in the models.

If series are individually $I(1)$ and cointegrated, there is a causal relationship among variables at least in one direction (Engle \& Granger, 1987). This causality direction is performed by applying the VECM of cointegration vectors. The Granger causality test is efficiently used for determining the causal relationship between two variables. In this study, the Granger causality approach is used for the investigation of the hypotheses based on the causality direction of variables for the shortrun association. Test results can be determined by using the chi-square value which shows the point of direction. VECM is suitable for indicating a short-run relationship between the variables in the analysis.

Table 6 shows the outcomes of the Granger causality test for Turkey by using chi-square value-related variables. The chi-square test result and $p$ value display a rejection of the null hypothesis which indicates no directional causality from health expenditure per capita to GDP per capita. There is a unidirectional relationship between health expenditure per capita and GDP per capita. Thus, as health expenditure increases, this raise has a significant impact on the GDP per capita. This result means that an increase in health expenditure is important in developing economic growth. This result is promoted by the study of Bektas and Ulutürk-Akman (2018).

Analysis through impulse-response function based on VECM is used in order to investigate the response dynamic influences of a model to certain shocks. Figure 1 displays the impulse-response functions of GDP changes caused by health expenditure, consumption, life expectancy at birth, trade, and FDI. In this study, results of the impulse-response function as 12 periods are indicated for related variables.

Figure 2a shows the output of the influences of health expenditure shock on GDP per capita. Health expenditure has a negative influence on GDP per capita in the fourth period. The influence of this shock changes after the fourth period. The ongoing impact of health shocks shows a large and positive influence on GDP from the fifth period to the eleventh period. This impact reaches to the highest point in the eighth period.

Figure $2 \mathrm{~b}$ shows the GDP per capita diagram of impulse-response function caused by consumption. As displayed in the figure, a shock causes GDP fluctuation. This figure shows that consumption shock has a positive influence on GDP per capita twice: from the first period to the fourth period and from the seventh period to the ninth period. The impact reaches the highest point in the third period. GDP declines after the eighth period and reaches the lowest point at the twelfth period, after returning to an increasing path.

Figure 2c displays the influence of life expectancy on GDP per capita. As shown in the figure, life expectancy causes a negative influence at almost all periods except the second and ninth periods. The impact reveals the lowest point in the fifth period. It can be noticed that the shock of life expectancy has a large influence on GDP per capita negatively. 

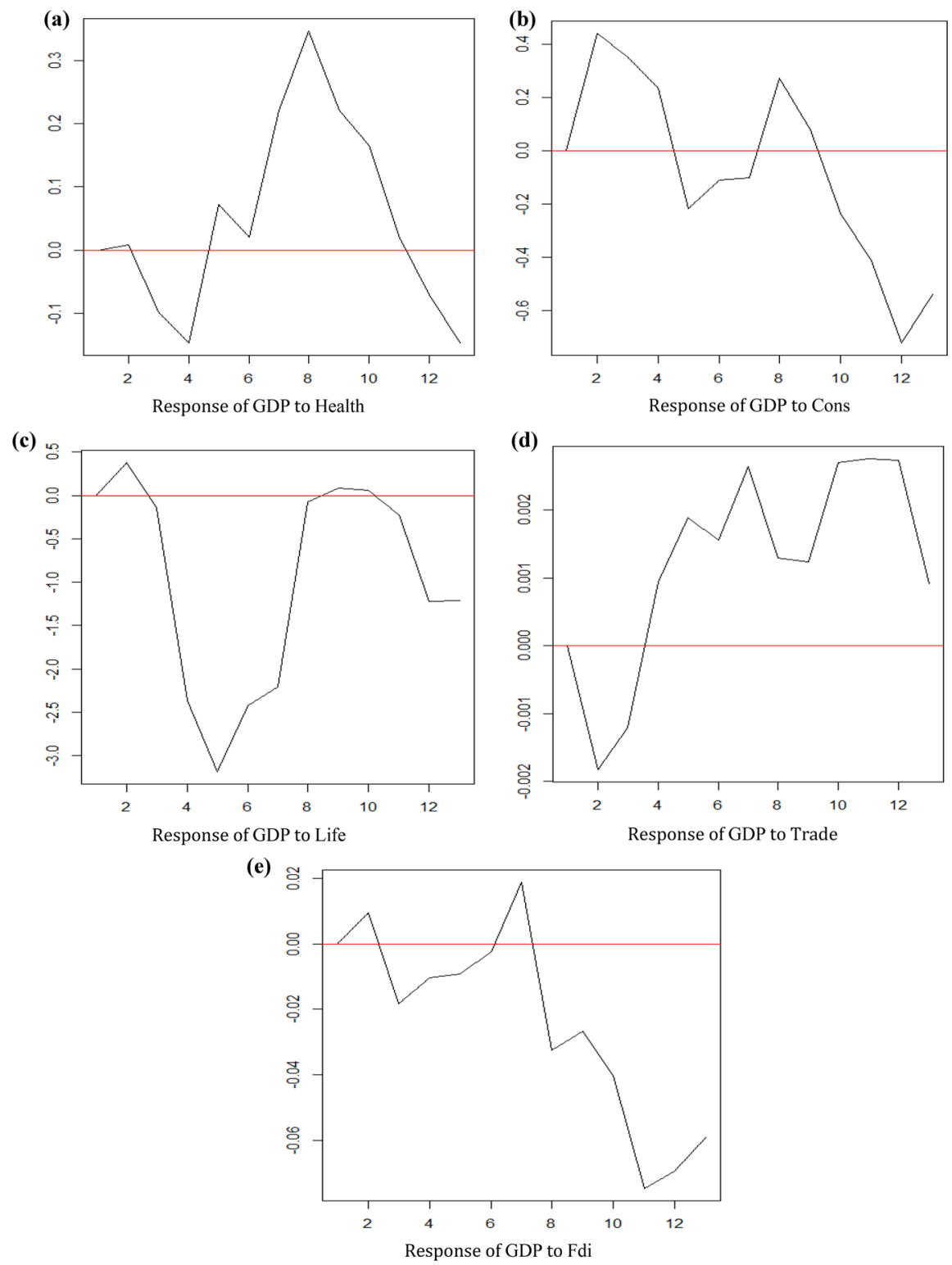

Fig. 2 Impulse-response function

Figure $2 \mathrm{~d}$ shows the impulse-response function of GDP per capita changes caused by trade. Even if influence of trade is seen negatively in the second period, there is an increase in the third period and this influence proceeds positively at all periods after the second period. The influence of trade shock on GDP per capita can be evaluated as positive. 
Figure 2e shows the response of GDP per capita to FDI shock. The impact of shock is negative from the second period to the sixth period. In the seventh period, the influence reaches the highest point as positive. The ongoing periods have a decreasing path and show a negative impact on GDP per capita after the seventh period.

\section{Conclusion and Policy Implication}

This paper empirically analyzed the relationship between economic growth and health expenditure by applying the time series data set for Turkey. For this purpose, stationarity on series, cointegration, causal relationship, and impulse-response function were tested to find out the extent of connection of GDP per capita and health expenditure. The achieved results from this study confirmed that there is a longterm relationship among all variables (GDP per capita, health expenditure per capita, household consumption per capita, life expectancy at birth, trade, and FDI) for Turkey. The long-term results display that the health expenditure and other variables play a significant role in a consistent economic growth process. Causality test results reveal that there is a unidirectional causality between health expenditure and economic growth for the related period in Turkey in the short term. An improvement in the health level of the population would result in an increase in GDP, through a healthier and more productive labor force.

Useful policy implications can be revealed from the results of this article. This paper suggests that health expenditure can be implemented as a factor that improves the human capital level and welfare of the population. These improvements are coordinated with the economic growth process. Moreover, the process of economic development is affected by the relation between economic growth and health (Bloom et al., 2018). It is important to approve that health expenditure has a supportive influence on economic growth but financing to the health industry does not lead to economic growth alone. Especially, other coherent terms and drivers should take part beside health expenditure in the short term.

In recent years, investments on health services such as enhancing capacity of hospitals and quality of services in Turkey provided the population's well-being to be increased. On the other hand, successful policies and implementations about fighting the COVID-19 outbreak displayed the importance of these investments. The current COVID-19 pandemic reveals that investments in the health sector are very important. The fact that people receive better health care in a country positively affects the welfare level of the country. Therefore, investments in the health sector should be encouraged and the share allocated by the government for health expenditures from the budget should be increased in Turkey. In order to raise the standard of living of the people in Turkey, technological developments in the health sector should be supported by the government. 


\section{References}

Ak, R. (2012). The relationship of health expenditures and economic growth: Turkish case. Journal of Business Management and Economic Research, 3(1), 404-409.

Akar, S. (2014). Türkiye'de sağlık harcamaları, sağlık harcamalarının nisbi fiyatı ve ekonomik büyüme arasındaki ilişkinin incelenmesi. Yönetim ve Ekonomi, 21(1), 311-322.

Akıncı, A., \& Tuncer, G. (2016). Türkiye'de sağlık harcamaları ile ekonomik büyüme arasındaki ilişki. Sayıstay Dergisi, 102, 47-61.

Atilgan, E., Kilic, D., \& Ertuğrul, H. M. (2017). The dynamic relationship of health expenditure and economic growth: is the health-led growth hypothesis valid for turkey? The European Journal of Health Economics, 18(5), 567-574.

Aydemir, C., \& Baylan, S. (2015). Sağlık harcamaları ve ekonomik büyüme İlişkisi: Türkiye üzerine bir uygulama. Dicle Üniversitesi Sosyal Bilimler Enstitüsü Dergisi, 13, 417-435.

Barro, R. J. (1991). Economic growth in a cross section of countries. Quarterly Journal of Economics, 106, 407-444.

Becker, G. S. (1964). Human capital. Columbia University Press for the National Bureau of Economic Research.

Bektaş, H., \& Ulutürk Akman, S. (2018). Examination of the role of health expenditures on economic growth: empirical evidence from Turkey. Kırklareli Üniversitesi İktisadi ve İdari Bilimler Fakültesi Dergisi, 7(3), 141-146.

Bloom, D. E., \& Canning, D. (2000). The health and wealth of nations. Science, 287, 1207-1209.

Bloom, D. E., Kuhn, M. \& Prettner, K.(2018). Health and economic growth. Discussing Paper Series, IZA DP No. 11939.

Çetin, M., \& Ecevit, E. (2011). Sağlık harcamalarının ekonomik büyüme üzerindeki etkisi: OECD ülkeleri üzerine bir panel regresyon analizi. Doğuş Üniversitesi Dergisi, 11(2), 166-182.

Dickey, D. A., \& Fuller, W. A. (1979). Distribution of the estimators for autoregressive time series with a unit root. Journal of the American Statistical Association, 74, 427-431.

Dickey, D. A., \& Fuller, W. A. (1981). Likelihood ratio statistics for autoregressive time series with a unit root. Econometrica, 49, 1057-1072.

Dreiger, C., \& Reimers, H. (2005). Health care expenditures in OECD countries: a panel unit roots and cointegration analysis. (p. 1469). Discussion Paper Series.

Eggoh, J., Houeninvo, H., \& Sossou, G. A. (2015). Education, health and economic growth in African countries. Journal of Economic Development, 40(1), 93.

Elmi, Z. M. \& Sadeghi, S.(2012). Health care expenditures and economic growth in developing countries: Panel co-integration and causality. Middle- East Journal of Scientific Research, 12(1), 88-91.

Engle, R. F., \& Granger, C. W. J. (1987). Co-integration and error-correction: representation, estimation and testing. Econometrica, 55(2), 251-276.

Erçelik, G. (2018). The relationship of health expenditure and economic growth in Turkey from 1980 to 2015. Journal of Politics Economy and Management, 1(1).

Grossman, M. (1999). The human capital model of the demand for health. NBER Working Paper Series. Working paper 7078 .

Halıcı-Tülüce, N. S., Doğan, İ, \& Dumrul, C. (2016). Is income relevant for health expenditure and economic growth nexus? International Journal of Health Economics and Management, 16, 23-49.

Hansen, C. W. (2013). Life expectancy and human capital: evidence from the international epidemiological transition. Journal of Health Economics, 32(6), 1142-1152.

Johansen, S., \& Juselius, K. (1990). Maximum likelihood estimation and inference on cointegration with application to the demand for money. Oxford Bulletin of Economics and Statistics, 52, 169-210.

Khan, H., \& Bashar, O. K. M. R. (2015). Social expenditure and economic growth: evidence from Australia and New Zealand using cointegration and causality tests. The Journal of Developing Areas, 49(4), 285-300.

Kiymaz, H., Akbulut, Y., \& Demir, A. (2006). Tests of stationarity and cointegration of health care expenditure and gross domestic product: an application to Turkey. The European Journal of Health Economics, 7(4), 285-289.

Lucas, R. E. (1988). On the mechanics of economic development. Journal of Monetary Economics, 22, $3-42$. 
Mankiw, N. G., Romer, D., \& Weil, D. N. (1992). A contribution to the empirics of economic growth. Quarterly Journal of Economics, 107, 407-437.

Mincer, J. (1974). Schooling, experience and earnings. Columbia University Press for the National Bureau of Economic Research.

Moscone, F., \& Tosetti, E. (2010). Health expenditure and income in the United States. Health Economics, 19, 1385-1403.

Mushkin, S. J. (1962). Health as an investment. Journal of Political Economy, 70(5), 129-157.

Obrizan, M., \& Wehby, G. L. (2018). Health expenditures and global inequalities in longevity. World Development, 101, 28-36.

Piabuo, S. M., \& Tieguhong, J. C. (2017). Health expediture and economic growth- a review of the literature and an analysis of the economic community for central African states (CEMAC) and selected African countries. Health Economics Review. https://doi.org/10.1186/s13561-017-0159-1

Romer, P. M. (1986). Increasing returns and long-run growth. Journal of Political Economy, 94(5), 1002-1037.

Romer, P. M. (1990). Endogenous technological change. Journal of Political Economy, 98(5), S71-S102.

Sethi, N., Mohanty, S., Das, A. \& Sahoo, M. (2020). Health expenditure and economic growth nexus: empirical evidence from South Asian countries. Global Business Review, 1-15.https://doi.org/10. 1177/s09721-509-20963-069

Turkstat. (2020). Health Expenditure Statistics. https://data.tuik.gov.tr/Kategori/GetKategori?p=saglikve-sosyal-koruma-101\&dil=1

WDI. (2020). World Development Indicators. https://databank.worldbank.org/source/world-developmentindicators

Yang, X. (2020). Health expenditure, human capital, and economic growth: an empirical study of developing countries. International Journal of Health Economics and Management, 20, 163-176.

Yıldırım, H. H., \& Yıldırım, T. (2011). Healthcare financing reform in Turkey: context and salient features. Journal of European Social Policy, 19(5), 178-193.

Publisher's Note Springer Nature remains neutral with regard to jurisdictional claims in published maps and institutional affiliations. 